\title{
Noget om de ældste titelblades typografi
}

af fagleder Poul Steen Larsen, Danmarks Biblioteksskole

De fleste bogmennesker har sikkert gennem årene undret sig over typografien på gamle bøgers titelblade, som f.eks. Christian Pedersens berømte Lagebog, trykt af hans trykkeribestyrer Johan Hoochstraten i 1533 (fig. 1). Efter nutidens tradition påfaldende overlæsset med dekoration, men helt almindeligt for den tid, med typografiens ofte totalt manglende hensyn til, hvad der er væsentligt og hvad der er uvæsentligt i værkets titel. Mere outrerede tilfælde findes let - f.eks. Peder Palladius' trøsteskrift til Frederik II, som tryktes af Christopher Barth i København i 1559 (fig. 2). Traditionen synes grundigt indarbejdet i 1500-tallets bogtrykkerkunst.

Denne praksis for bogtitlers typografiske udformning opstod med de ældste, egentlige titelblade fra 1490'erne og holdt sig lige til barokken omkring 1600-tallets midte, hvorefter titeludformningen - inden for rammerne af de efterfølgende stilperioders skiftende, æstetiske smag - stort set ligner vore dages måde at titelgive bøger på, med de væsentligste oplysninger, især titlen, fremhævet som et typografisk hele i titelbladets største skriftgrad.

Emnet for dette lille essay er blot om en detalje i titelbladets lange historie, der er så udmærket sammenfattet i Carl Björkboms Titelbladets Historia (1937). Den stadigt uløste gåde er imidlertid de allertidligste titelblades særprægede typografi og æstestik.

Spørgsmålet lyder derfor i sin enkelhed: Under hvilke omstændigheder giver Renaissancens titeludformninger den bedst mulige mening til deres bøger? Eller mere alment udtrykt: Hvilken slags mening kan der have ligget i disse grafiske opsætninger? 


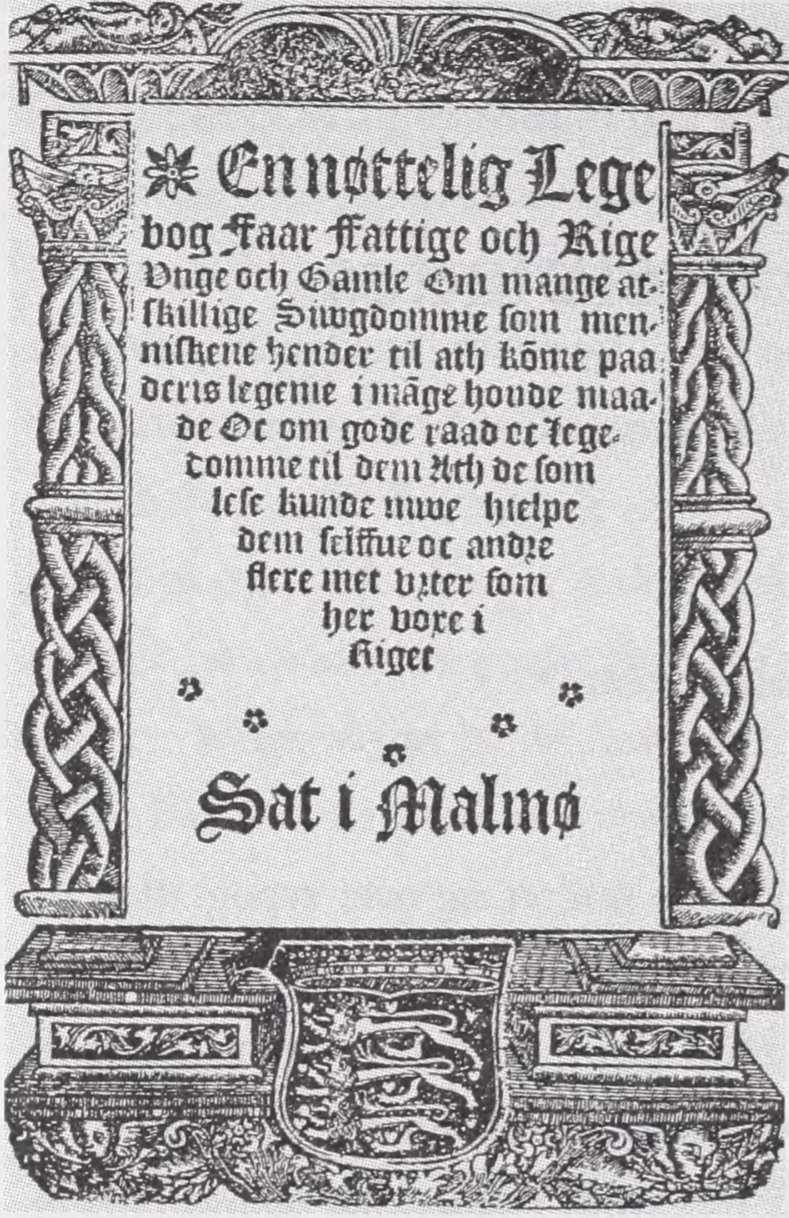

Fig. 1. En nøttelig Legebog. Ved Christian Pedersen. Malmø: Johan Hoochstraten, 1533.

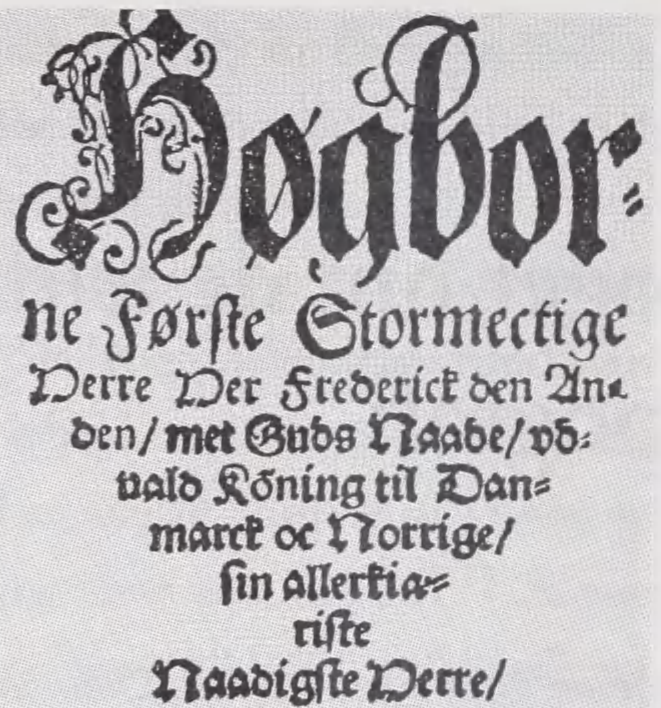

\section{สil[creffuit affbans Iaadis Dnoerfatte}

petro pallasio.

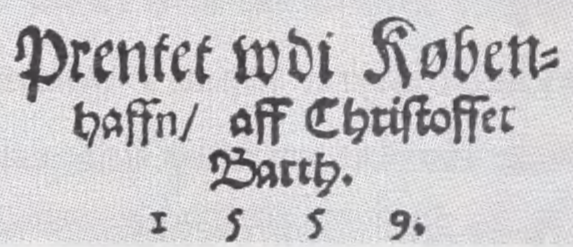

Fig. 2. Hogborne Forste Stormectige Herre. Af Peder Palladius. København: Christopher Barth, 1559.

Skønt der forekommer talrige mellemformer, kan de tidlige titelblade alligevel groft opdeles i kun to hovedtyper: For det første er der den store gruppe (A) titelblade, som har typografien indlagt i en dekorativ ramme. Rammen kan vise antikke, bibelske eller rent dekorative motiver, eller - som specielt i Tyskland - et sceneri af personer, der får titelfeltet til at ligne en opklæbet plakat midt på et billede. I Sverige og Danmark sås ofte en formaliseret altertavle, som f.eks. i Christian Pedersens Lagebog.

Den anden tradition er (B) de hovedsageligt typografiske titelblade, hvis midte prydes af et bogtrykkermærke. Denne type var særligt fremtrædende i Italien og Frankrig, som f.eks. i Aldus og Etiennes udgivelser.

Man antager oftest at (A) de træskårne rammer har haft deres forbillede i middelalderens illuminering af håndskrevne bøger, hvad der i særlig udstrækning praktiseredes på bøgernes første ordinære rectoside. Overgangsstadiet var bogtrykte, asymmetriske rammer sammesteds, som f.eks. i Ratdolt \& Malers udgave af Appianus' Historia Romana fra 1477 (fig. 3). Forvandlingen af første recto til en titelside 


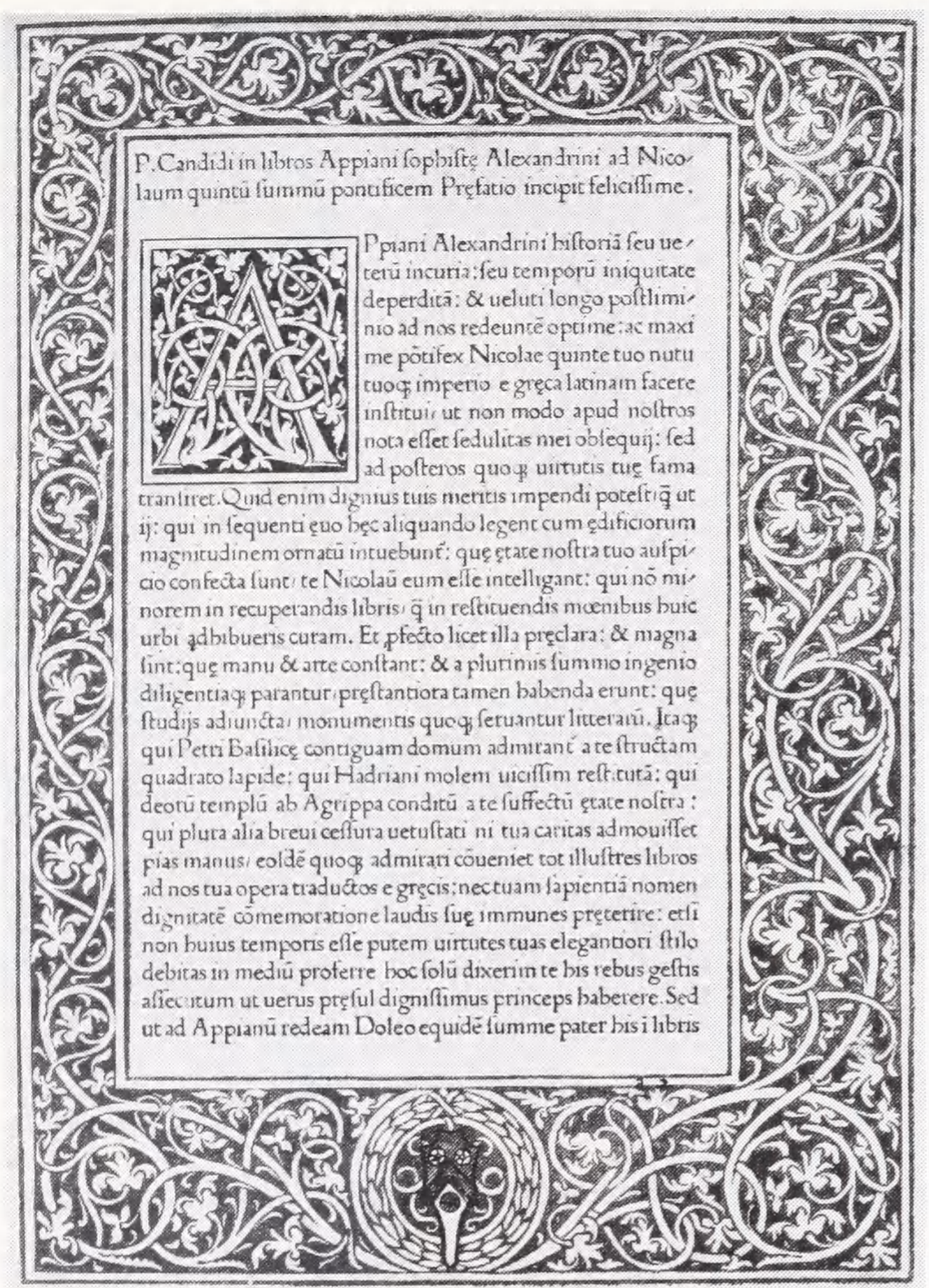

Fig. 3. Historia romana. Af Appianus. Venezia: Maler, Ratdolt \& Löslein, 1477.

fandt sted i 1490'erne og krævede vel ikke stor opfindsomhed - men den tildelte dog rammen en helt ny funktion.

Fra at være dekoration i forhold til værkets indledende tekst blev rammen nu en appetitvækker for værkets indhold i dets helhed.

Med denne funktion for øje var det oplagt at lade rammen forestille en åbning, en indgangsportal eller lignende, der kunne opleves som det billedlige udtryk for tidligere, titelløse bøgers bogtrykte „INCIPIT“ (d.v.s. „her begynder-“). Rammen skulle være et billede, der kunne sige: „kom, her skal du se!“. Og en særlig respekt for værkets autoritet og lødighed skabte man med titelrammernes mindelse om enten altertavler eller klassisk-romerske monumenter. Hvad der her er trykt, det står til troende! Det er gamle sandheder. Se f.eks. Johann Froben-udgaven af Lucubrationes, d.v.s. „studier ved nattetide“, fra 1523, hvor titlen gemmer sig i fjerde linies brødskrift (fig. 4), og hvis titelramme er tegnet i svagt højrestillet relief, hvilket viser dens oprindelse i illumineringer af første rectoside.

Efterhånden måtte titelrammen dog forlade sit oprindeligt assymetriske design 


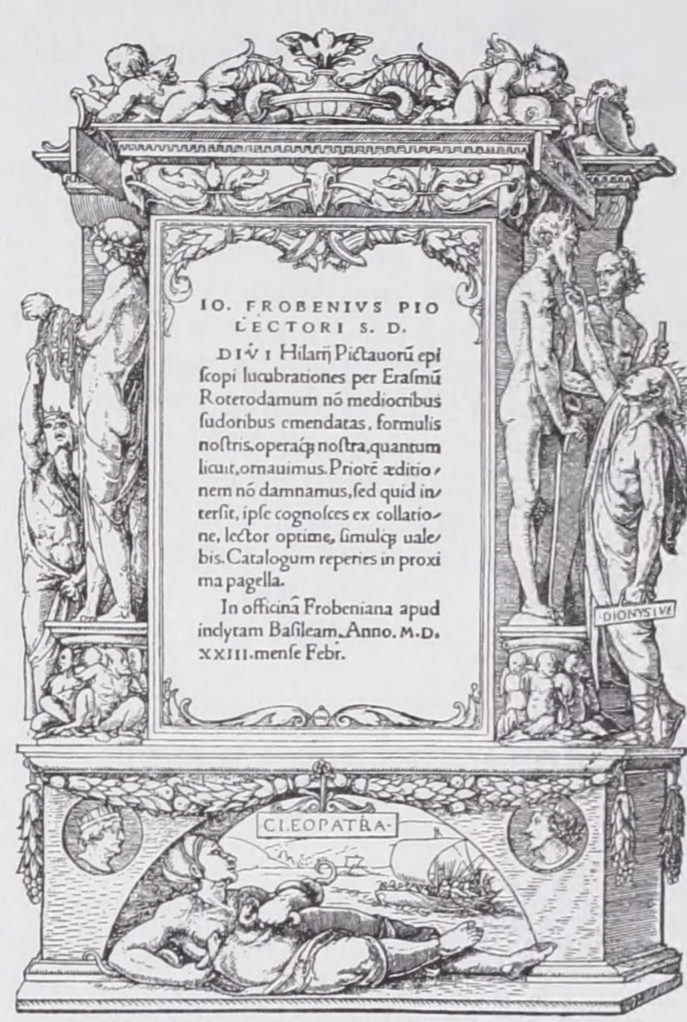

Fig. 4. Lucubrationes. Af Hilarius, biskop i Poitou. Basel: Johann Froben, 1523.

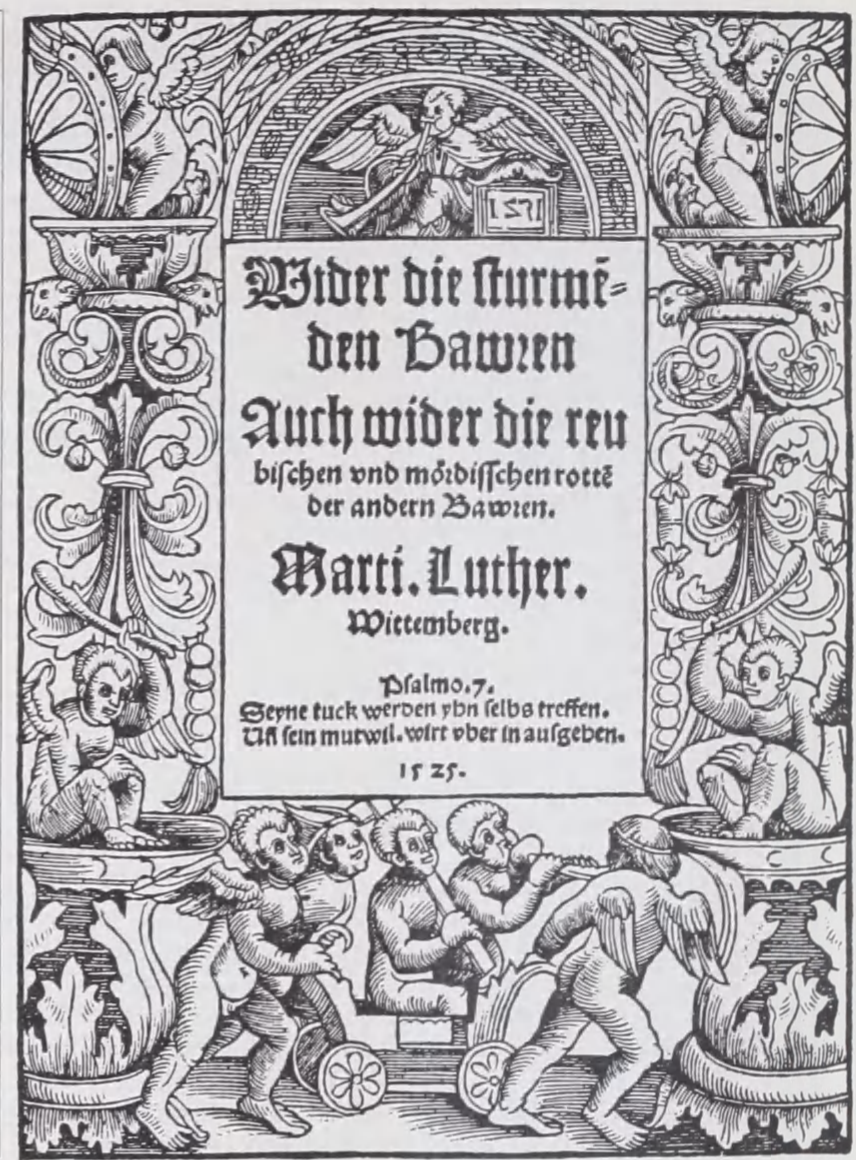

Fig. 5. Wider die sturmenden Bawren. Af Martin Luther. Wittenberg: Jörg. Rhau, 1525.

i overensstemmelse med de bogtrykte tekstfelters placering på siden efter margenforholdenes klassiske proportioner 3, 5, 8, og 13, „det gyldne snits"s proportioner. Titelsiden skulle nu præsentere sig symmetrisk. Den lige vej fra læsernes blik ind i værket, som f.eks. titelbladet til Luthers bandbulle mod de oprørske bønder i 1525 (fig.5). Eller Oronce Finés udgave af Euclids geometri fra 1536 (fig.6); her går læseren lige ind i værket.

Så meget nu om selve den indramning, der kendetegner den førstnævnte type titelblade, og hvis interessante motivhistorie er vidt beskrevet i faglitteraturen. Den anden type tidlige titelblade er kendetegnet først og fremmest ved deres typografi og ofte forekommende bogtrykkermærke. Velkendt er Aldus' anker og delfin, som fx. på titelbladet af hans udgave af Ovids Forvandlinger fra 1502. Titlen ser vi først midt på titelbladet i spærrede versaler (fig.7).

Det er velkendt, at bogtrykkermærker benyttedes allerede af Fust \& Schøffer i 1457 og af talrige andre, f.eks. af Ratdolt, Caxton, Reuwich, Giuntaerne - og i Danmark af Poul Ræff fra 1531. Også at bogtrykkermærker i begyndelsen tryktes til sidst i bogen, som en slags segl eller signet.

Bogtrykkermærket udbredtes i takt med bogtrykkernes stigende selvbevidsthed 


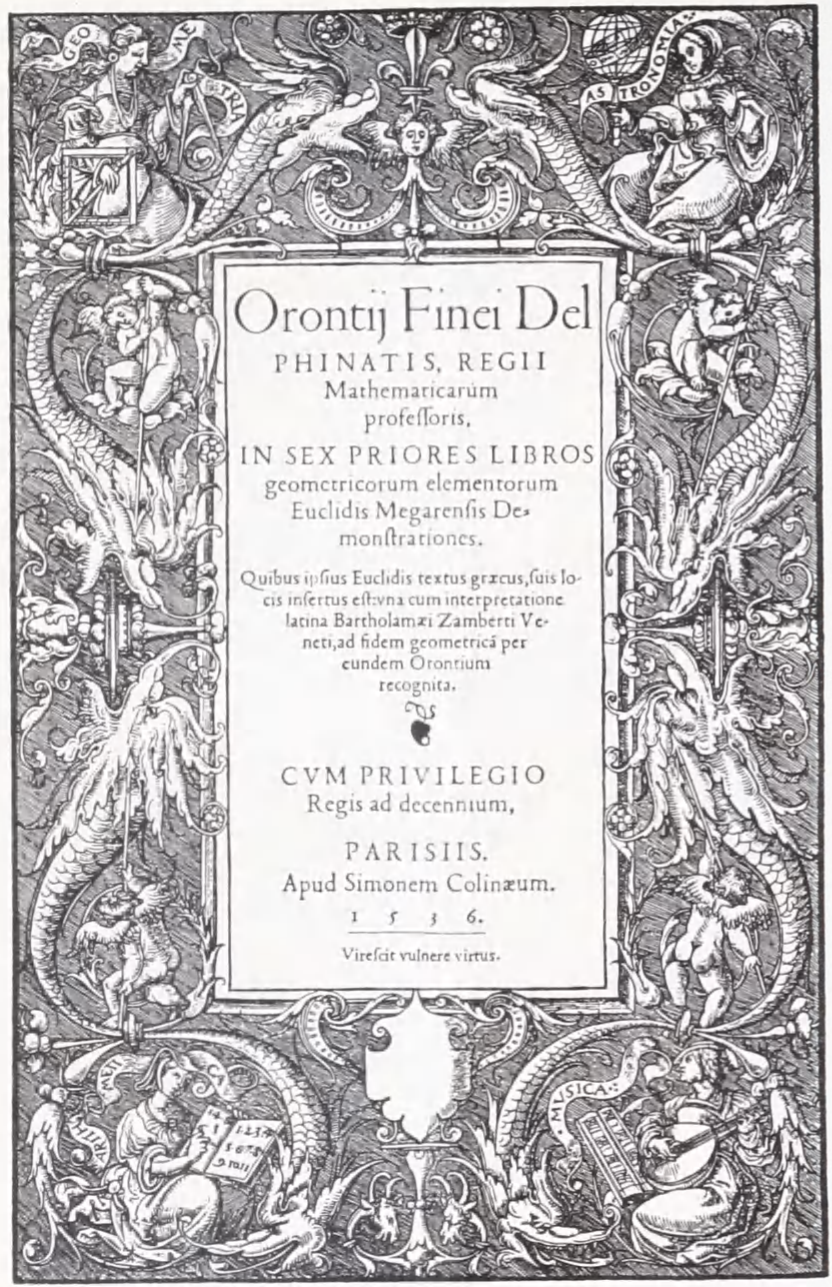

Fig. 6. Libros geometricorum elementorum Euclidis. Ved Oronce Finé. Paris: Simon de Colines, 1536.

og blev, især til den akademiske litteratur, ofte en slags „garantistempel“ for teksternes filologiske kvalitet. Det er også velkendt, at disse bogtrykkermærker efterhånden vandrede fra kolofonen frem til den såkaldte „bastardtitel“, en kortfattet, oftest enkeltliniet titelangivelse på bogens omslag. Bastardtitlen havde oprindeligt blot været en håndskrevet mærkning af, hvilken trykt bog, der gemte sig indeni. Undertiden var det en bogtrykt strimmel papir, der blev foldet om første læg. Større bøger blev jo endnu o. 1500 oftest leveret i materie med henblik på kundens egen indbindning.

Og - en passant - blev jo heller ikke bogbindet på denne tid præget med hverken forfatternavn eller titel. Bogbindet var ejerens private udstyrelse af sit eksemplar, og det blev derfor præget med dets ejers insignier, som f.eks. våbenskjold eller motto, men havde intet med bogens titel eller emne at gøre. Først hvis man havde rigtigt mange bøger i sit bibliotek kunne det være nyttigt for ejeren at male et nøgleord på bogblokkens forsnit, eller at klistre en etiket uden på skindbindet - men det var som regel forfatterens navn, sjældent bogens titel.

Den typografiske udformning, som titelbladets tekst blev presset ind i, var et tilsyneladende meningløst liniefald - uden hensyn til, hvad der i titlen var væsentligt 
QVAEHOC VOLVMINE CONE TINENTVR.

Ad Marinum Sannutum epifola' qui apud gre. $\cos$ fripferint $\mu \varepsilon \tau \propto \mu о \rho \phi \omega ́$ o :s.

Aldo priuilegum conce]fum ad reip. literarie wais litatem.

orthographia dictionum greatrum per ordi= nem literarum.

vita ouidÿ ex ipfius operib.

Index fabularum et ceterorum, que infunt hoc libro fecundum ordinem alphabeti.

OVIDIT METAMORPHOSE $\Omega N$ IIBRI QVINDECIM.

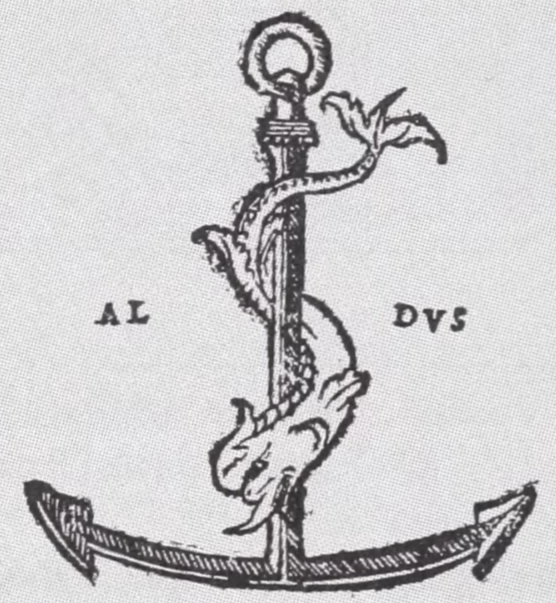

Fig. 7. Metamorphoseon libri quindecim etc. Af Publius Ovidius Naso. Venezia: Aldus Manutius, 1502.

og uvæsentligt. Man affattede titelteksten i et mundret prosasprog som, afhængigt af om det var latin, fransk, tysk eller andet, fik de oplysninger, vi i dag opfatter som bogens „titel“ og katalogiserer bogen efter, placeret på naturlige - men typografisk set vilkårlige steder i titelteksten. Efter denne praksis ville titlens vigtigste ord sjældent komme til at stå hverken først eller på nogen anden prægnant position på titelbladet.

Denne praksis synes at være hentet fra især norditalienske kolofoner og rubrikafslutninger, hvori brødskriftens liniefald ofte havde særprægede former. Almindelig var den omvendte triangel, hvis tekst løber ned i spids, som fx. i Aldus' berømte 1499-udgave af Colonnas Hypnerotomachia Poliphili (fig.8). Hermed var læseren varskoet om, at kapitlet eller hele værket bevægede sig mod afslutningen, mente den amerikanske bogtrykker Theodor Low De Vinne i sit stadigt uovertrufne lille værk $A$ Treatise on Title-Pages fra 1904, en bog med stor og mærkværdigvis overset indflydelse på boghåndværket i Norden i begyndelsen af 1900-tallet, specielt gen- 
Fig. 8. Hypnerotomachia Poliphili. Af Francesco Colonna. Venezia, Aldus Manutius, 1499 .
PRIMVS

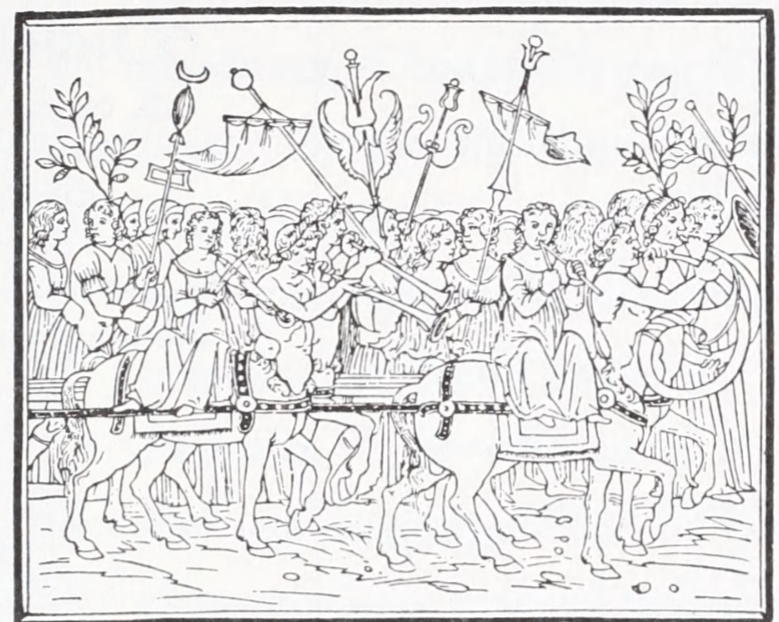

EL SEQVENTE triúpho nó meno mirauegliofo đll primo.Impo che egli hauea le qutro uolubile rote tutte, \& gli radii, \& il meditullo defu fco achate, di cádide uéule uagaméte uaricato. Ne tale certańte geftoe re Pyrrho cúle noue Mufe \& A polline i medio pulfäre dalla natura ípffo. Laxide $\&$ la forma del dicto öle el primo, ma le tabclle eráo di cyaneo Saphyro orientale, atomato de fcintillule doro, alla magica gratiffimo, \&longo acceptiffimo a cupidine nella finiftra mano.

Nella tabella dextra mirai exfcalpto una infigne Matróa che dui oui hauea parturito, in uno cubile regio colloca ta, di uno mirabile pallacio, Cum obftetrice Itu pefacte, \& multe altre matrone \& aftante NympheDegli quali ufciua de uno una flammula, \& delal, tro ouo due fpectatifli me ftelle. **

nem de Vinnes nære venskab med xylograf F. Hendriksen, som i alt sit virke for bogæstetikken formidlede netop de Vinnes tanker til nordiske kolleger.

Skønt titelsatsen indleder værket - og ikke afslutter det - er titelsatsen selv en afsluttet rubrik med sin særlige opgave. Andre, mere almene, faktorer har naturligvis også spillet ind, f.eks. blot smag og behag, som Bjørkbom mener er hovedårsagen. Og datidens konventionelle typografiske layoutforskrifter, hvorefter bestemte skriftgrader skulle benyttes til bestemte linier, således som Sten G. Lindberg hævder (i: Svensk Grafisk Arsbok 1972, s. 23-25). Gradsforskellene i liniefaldet varierer dog så meget i europæiske 1500-tals bogtryk, at der næppe har været én bestemt fælleseuropæisk æstetik på det område. Per Ridderstad har i sin interessante disputats, Konsten at sätte punkt (1975) indgående behandlet renaissancehumanisternes interesse for antikkens stenskrift, der bør betragtes som udslag af den samme sans for alfabetets grafiske monumentalitet som den, vi møder i titelbladstypografien. 
Fig. 9. Dialogue de la Vie et de la Mort. Af Innocente Ringhicor. Lyon: Robert Granjon, 1557.

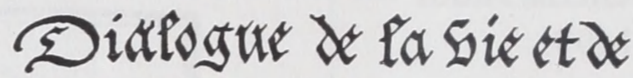

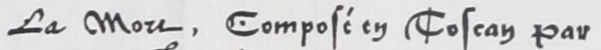
Maiffer fonnoctur Eingficue Sentilfomme Bsonlongnois.

*

Monnelermeme trad uit ey. francoyos par Johay Lonnean Letertur of CSaftilloy \& gembes.

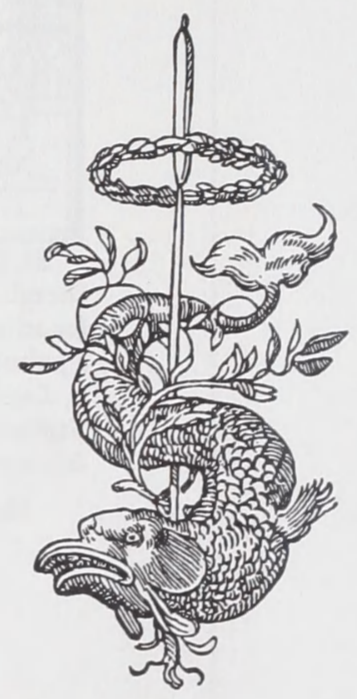

$$
\text { I } \text { fyoy. }_{\text {. }}
$$

L'Imprimerie \& E. Eobert Sranfoy. mil. So. $\angle$ sij.

Men formentlig har bogtrykkerne også haft et ganske enkelt ønske om at pynte på deres bøger - specielt i 1490'erne, da man i den hårde priskonkurrence om kunderne oftere og oftere undlod en fordyrende rubricering, som tidligere havde været det normale „finishing touch“, der havde fået bøger til at ligne håndskrifter.

Det var også på den tid at de første kommercielle sortimentsboglader (modsat universiteternes staionarii og bogtrykkernes egne udsalg) etableredes i de store handelsbyer, Venedig, Nürnberg, Augsburg og Leipzig. Før havde omvandrende „bogførere “ i højere grad kunne rekommandere deres bøger mundtligt. I bogladen med det vidtspændende udvalg skulle kunden derimod vælge sine bøger ved selvsyn. At titelbladet netop fra 1490'erne fik karakter af et reklameskilt med opsigtsvækkende typografi er derfor ikke ubegribeligt, og det befæster sin position yderligere efter år 1500, da titeludbuddet på bogmarkedet eksploderede som en følge af især kirkelige stridigheder, som den engelske historiker Martin Lowry har påvist bl.a. i Venetian Printing (1989). 
C IMPRESSVM ET COMPLETVM EST PRESENS chronicarum opus'anno dru. M D XV.in uigilia Marga retse urginis. In nobili famolads urbe Mogunntina, he ius arnis imprefítory inuentrice or im2 F a IOANNEM Schoffer, nepote quödis honeftiuirilO ANNIS fufth gurs Moguntein, memor arc artis primarn aucioris Quitandétmprimendi artí proprio ingeniocx.

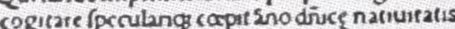
M CCCC.Lndicuó XJII. Regnaniesllu Atrfimo Ro.Imperatore FREDERICO ili. Prefidentefancta Mogununx fedis Reucièdifimo in chro pie domino THEODERICO PIncenadc Er Paricior Pachpripe eictorc Anno aus

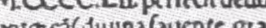
ia na) in opus inpriméd Opera triacmulnis accitharts 2 din Icnuonsuls PETRI Schofira dc Gernswiminis triluch tiln adoptio w) Cuictamminimam CHRSTINAM furturín $P$ digna labotú multarúgadinus

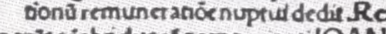
tincrüt aourthij duolapryominad OANNES furth QP ET bussounitris a famlianbus cons ne lla quoqmodo man

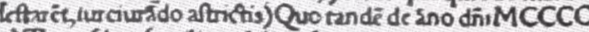
XII $R$ cofdem familiaresi diver fas terrase puncias durulgat haud parum fumplit icremenium.

CVM GRATIA ET PRIVIEGIO CAESAREE MATE:

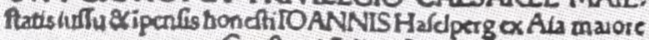
Conftanticidiocefis:

Fig. 10. Chronica. AfTrithemius. Mainz: Peter Schöffler, 1515. Kolofonen.
Specielt opsigtsvækkende var liniefald i stærkt aftagende skriftgrader, normalt aftagende ned til brødskriftens grad. Her kunne læseren bevæge sig trinvis fra tekstreklamen ned til bogtrykkerens reklame for sig selv og bogens impressum. Som f.eks. i Granjons 1557udgave af Ringhicors Dialogue de la Vie et de la Mort (fig. 9), der ydermere er sat med Granjons egen, særprægede Civilité-skrift. Man skal næppe se nogen teologisk åndrighed $\mathrm{i}$, at 'døden' er sat i mindre grad end 'livet'.

Der er flere mulige og enkle forklaringer på disse umiddelbare meningsforstyrrende gradskrifter og liniefald i det, vi i dag oplever som titlens „slagtekst“.

For det første brugte man i forvejen uens skriftgrader til initialord, hvor et enten indmalet eller senerehen bogtrykt initial kunne være helt ude af proportioner med resten af sit ord. For det andet var der i Renaissancen en tradition for, at bogstaver kunne have et 'eget liv' som kunstværker, at de kunne være en slag arkitektur - løsrevet fra ethvert sprog. Specielt versalerne, som jo havde deres oprindelse i den romerske capitalis quadrata, og var nært knyttet til antikkens bygningskunst. Associationen var oplagt i en tidsalder hvor alt hvad der var antikt - ikke mindst geometrien - blev dyrket af humanisterne som en slags religion. De lærde læseres smag blev til bogtrykkerens konventioner. Som f.eks. kolofonen til Trithemius' Chronica i Schøffers udgave fra 1515 (fig.10), eller Paul Grijs' Psaltarium (fig.11), der tryktes i Uppsala i 1510.

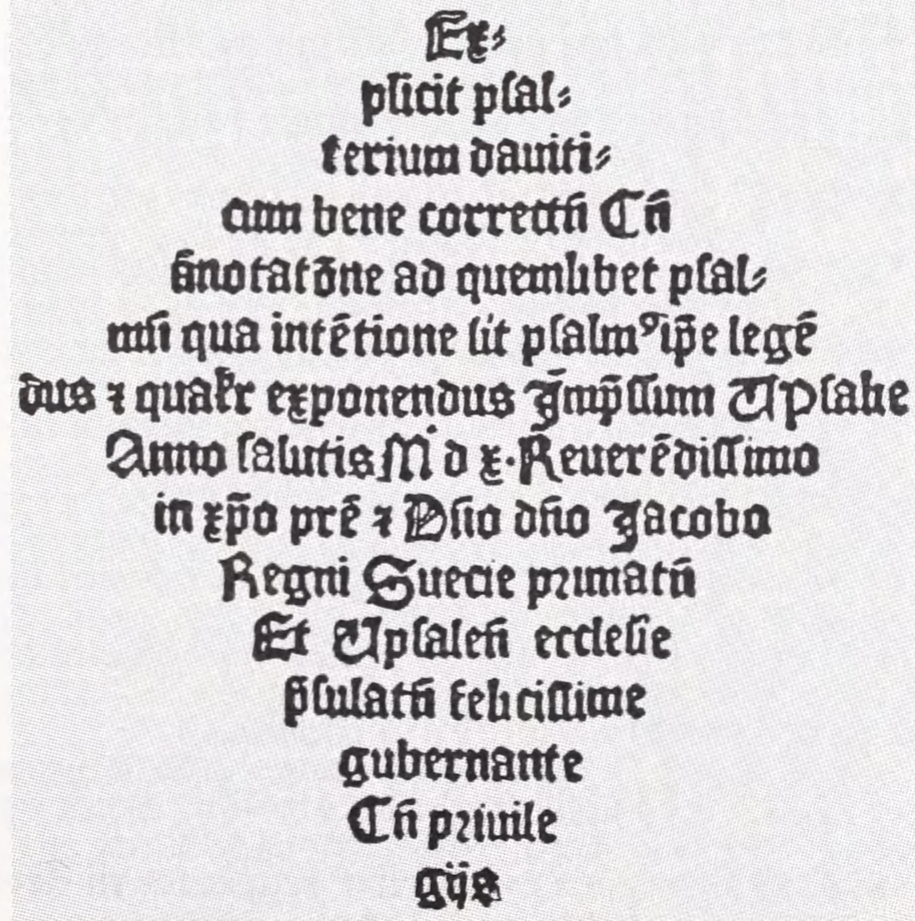

Fig. 11. Psalterium. Uppsala: Paul Grijs, 1510. Kolofonen. 
Vi møder i Renaissancen en fra antikken stammende formglæde, som er vor egen tid fremmed. En lyst til i det konkrete kunstværk også at demonstrere værkets forankring i almene ideer. Inden for den humanistiske litteratur affødte denne ambition en stærk optagethed af skrift og typografi. Oplevelse af sammenhæng mellem budskabets form og formlære i almindelighed har utvivlsomt medvirket til at man gennem bogtrykkerkunstens de første 150 år oplevede titelsats mere som en slags tegn, end som en slags tekst.

Denne skriftkult var blevet grundlagt i det sydlige Europa af lærde, som Felicio Feliciano i 1470 'erne, med inspiration fra berømte arkitekter som Leon Battista Alberti, og den videreførtes i 1500-tallets første halvdel af bogkunstnere som Geoffrey Tory. Lige siden har skrift og typografi haft deres dobbelte tilhørsforhold til såvel bogtrykkerfaget som til arkitektuddannelserne.

I hele den lange periode ser vi, parallelt med tegntypografiens blomstring, en tilsvarende formalisering af digterkunsten, som den vi møder f.eks. hos George og Richard Puttenham i den ene af brødrenes (ingen ved endnu hvilken) Arte of Englishe Poesie, en poetik fra 1589 med nøje anvisning på de forskellige slags firkantet, rund eller trekantet satsopbygning der egner sig til poetisk tekst. Meningen var ikke som det siden blev for barokkens digtere - at formen skulle udtrykke indholdet, som det man har kaldt „ekspressiv typografi“. Meningen var snarere - som i antikkens carmina figurata - at indholdet skulle tilpasses formen, d.v.s. at teksten skulle skrives som en udfyldningsopgave inden for en på forhånd given, meget stram form. Kunsten var i høj grad at kunne overholde formens krav.

Holdningen kunne hos nogle forfattere udarte til ren kryptificering af tekstens mening, fordi teksten skulle skrives ind i en tvungen form af f.eks. sproglig art. Udover Hypnerotomachia Poliphili kunne man nævne meget senere værker som englænderen John Lylys Euphues fra 1579, der i vore dage er næsten ulæselig på grund af sprogets stringente floromvundethed, som kun Renaissancens læsere forstod at påskynde. Eller så sent som i 1600-tallets begyndelse dedikationen i 1609-udgaven af Shakespeares Sonnets (fig.12), et berømt eksempel på sproglig formtvang, som formentlig har været en intellektuel nydelse for datidens læsere - men fortsat er en litterær mystifikation for nutidens.

Når titelbladets slaglinier ofte blev brudt op i aftagende skriftgrader skyldtes det også, at stavelserne ville blive reduceret til det sprogligt helt uforståelige, hvis ikke man gik ned i skriftgrad efter første linies pyntebogstaver. Med den triangulære 


\section{TO.THE.ONIIE.BEGETTER.OF.} THESE. INSVING . SONNET S.

Mr.W.H. ALL.HAPPINESSE.

\author{
AND.THAT.ETERNITIE. \\ PROMISED.
}

BY.

OVR.EVER-LIVING.POET.

WISHETH.

THE . WELL-WISHING.

ADVENTVRER . IN.

SE T T IN G. FORTH.
Fig. 12. Shakespeares Sonnets. Neuer before Imprinted. London: G. Eld for T.T., 1609. Dedikationen.

\section{T. T.}

form sikrede sætteren sig yderligere på en nem måde, at titelsatsen blev symmetrisk, fordi den trinvis nedefter hele tiden blev udsluttet med det samme antal kvadrater både til forkant og bagkant. Og symmetrisk skulle typografien helst være.

Man bør heller ikke glemme, at enhver poet siden oldtiden selvfølgelig har vidst, at læserens opmærksomhedskoncentration skærpes, jo kortere verslinierne gøres! Og liniefald var også en måde, hvorpå læserens opmærksomhed trinvis kunne skærpes.

Jeg tror det lønner sig at opleve Renaissancens typografiske „udskejelser“ udfra sådanne forudsætninger... Der var ofte intet „tekstligt “ budskab i disse særprægede slags titelsats. Budskabet var rent formelt, det var grafisk, og det triangulære satsfelt alene prædestinerede til en opmærksomhedsskabende formulering af, hvad det var for en slags værk, kunden havde for sig. Endelig er det vigtigt også at opholde sig lidt ved selve begrebet bogtitel. 
Som tekst eller værk forfattes en bog som et forløb, der for en forfatter selv oftest rummer en stor mangfoldighed af delemner. Først når bogen er færdigskrevet, opstår behovet for at give denne mangfoldighed én sammenfattende betegnelse, en titel. Men hvordan dog sammenfatte så mange delemner i ét enkelt, kort udtryk, der skal være dækkende for helheden? Det er en klassifikatorisk opgave, som kan være svær og føles noget uvedkommende for kun en af selve værket optaget forfatter. Titlen er udgiverens og læserens anliggende. Det er udgiverens, fordi bogen skal kunne markedsføres. Det er læserens, fordi den siden skal kunne huskes!

Antagelig har bøger i den tidlige Renaissance almindeligvis - ligesom middelalderens håndskrifter - været husket fortrinsvis i kraft af deres ophav, d.v.s. deres forfatter og evt. kommentator. Forfatterne var antagesesvis meget færre end antallet af titler på bogmarkedet og derfor betydeligt lettere at huske. De samme forfattere skrev jo også på den tid om alverdens forskellige ting. Conrad Gesners Bibliotheca Universalis (1545-55) var fornuftigvis af den grund en rent forfatter-ordnet bogfortegnelse, hvis umådelige spændvidde understøtter troen på, at Renaissancens lærde - ihvertfald indtil bogmarkedet eksploderede i vækst i 1500-tallet - hver især har kendt til al væsentlig litteratur. Titler ville - udfra denne antagelse - slet ikke have den samme vigtige rolle for læseren, som de har i vore dage.

Den virkeligt interesserede i bøgers titel var bogudgiveren. Han havde - dengang som nu - oftest sin primære interesse i bogen som en salgsartikel. Han lancerede titelbladet i den grafiske form, som han inden for bogens budget anså for mest opmærksomhedsskabende. Og til dette formål behøvede han ikke føle sig bundet af „forståelsestypografien“! Han kunne frit boltre sig i „tegntypografi“, hvad vi i vore dage vil kalde reklamegrafik.

Som hovedregel tilhører begrebet „bogtitel“, i moderne forstand, tiden efter 1600-tallets midte - startende i baroktiden - da typografien blev kraftigt mobiliseret i opbyggelsens tjeneste, og da bibliotekernes behov for ordning af store bogsamlinger affødte en tilsvarende stor interesse i titelkataloger og emnordningssystemer. Renaissancens titelblade var ikke belastet af vore dages forestilling om "bogtitler". De havde deres eget budskab som grafiske former med rod i såvel middelalderlige håndskrifttraditioner som i deres egen tidsalders udbredte formglæde og den ældste bogtrykkerkunsts praktiske vilkår. 